\title{
Farmers' Responses to Land Use Change from the Paddy Field to Cocoa Plantation in Dlingo Sub-District, Bantul Regency
}

\author{
Rizki Yusnanda ${ }^{1}$, Sriyadi $^{1}$, Zuhud Rozaki ${ }^{1 *}$ \\ ${ }^{I}$ Department of Agribusiness, Faculty of Agriculture, Universitas Muhammadiyah Yogyakarta, Yogyakarta, 55183, Indonesia \\ ${ }^{*}$ Corresponding author. Email: zaki@umy.ac.id
}

\begin{abstract}
Agriculture land uses change to become a serious issue in Indonesia. Farmers tend to change their land to more economical usage. This study aims to determine the farmers' responses toward land use change from the paddy field to cocoa plantation in Terong Village, Dlingo Sub-district, Bantul Regency. 60 respondents were interviewed using structured questionnaire. Scoring was used to describe the response, and Rank Spearman analysis was used to analyze the factor that effecting the response. Results show that education has a significant positive correlation with knowledge regarding land use change, farm size has a significant correlation with action and income has a significant correlation with attitude. Generally, farmers' response toward land use change are not bad because the change is still within agriculture practices.
\end{abstract}

Keywords-Farmers' response, land use change, paddy fields, cocoa plantation

\section{INTRODUCTION}

Agriculture land time by time continue to decrease, the cause of this phenomenon are vary but commonly change to settlement or industry [1]. Agriculture sector recently is felt cannot be a single livelihood due to the increase in production cost which is not followed by agricultural product income. Some areas try to develop their agriculture by diversifying the potential crop [2]. But unfortunately, some of them are not success with only changing crop. Therefore in the field, some farmers change their paddy field to plantation with plants that can produce more income for them.

The plantation is agricultural practice that needs more time in the production process. One of the commodities that has high potency in development is cocoa. International and local demand for cocoa is continued to grow [3]. Agricultural land use change to cocoa plantation has a negative effect on decreasing the productive agricultural land [4]. Some of parties maybe think that as long as the agriculture land use change still within agricultural use, such as cocoa plantation, is not problem. But it must be considered about the decrease of other commodities which can produce periodically such as paddy.

Special Region of Yogyakarta is trying to develop cocoa, which is dominated by Kulonprogo Regency and Gunungkidul Regency (as seen in Table 1), it is not only to produce products that getting more popular, but also can support the tourism such as providing chocolate from local cocoa for tourists. [5] found that tourism takes a role in peoples' economic when cocoa business is declining. But, the current situation shows that cocoa businesses can support tourism, so they both are becoming economic source together. Bantul Regency has the smallest area for cocoa plantation, and local government made program for expanding cocoa plantation, one of the places included in this program is Terong Village in Dlingo Subdistrict.

The main reason for the government made a cocoa production center in Terong village is because there is the potency of this area to be planted with cocoa, so the government took the initiative to make a program for expanding cocoa plantation.

Table 1. Cocoa Plantation Area and Production in Special Region of Yogyakarta

\begin{tabular}{|l|c|c|c|c|c|c|}
\hline \multirow{2}{*}{ Regency } & \multicolumn{2}{|c|}{$\begin{array}{c}\text { Land Area } \\
\text { (Ha) }\end{array}$} & \multicolumn{2}{c|}{$\begin{array}{c}\text { Production } \\
\text { (Ton) }\end{array}$} & \multicolumn{2}{c|}{$\begin{array}{c}\text { Productivity } \\
\text { (Kg/Ha) }\end{array}$} \\
\cline { 2 - 7 } & 2016 & 2017 & 2016 & 2017 & 2016 & 2017 \\
\hline $\begin{array}{l}\text { Kulon } \\
\text { progo }\end{array}$ & 3,587 & 3,587 & 862 & 843 & 240.65 & 235.02 \\
\hline $\begin{array}{l}\text { Gunung } \\
\text { Kidul }\end{array}$ & 1,422 & 1,422 & 319 & 375 & 224.33 & 263.71 \\
\hline Sleman & 104 & 87 & 9 & 19 & 86.53 & 218.4 \\
\hline Bantul & 48 & 66 & 1 & 1 & 20.83 & 15.15 \\
\hline
\end{tabular}

Actual when the government makes program regarding agricultural commodities' development, they need to analyze which commodity that has potency [7]. The cocoa program brought another issue in this area, which is some areas that being used for cocoa plantation were paddy fields before. This condition drives this study to be done. This research aims to 
determine the farmers' response toward agricultural land use change from paddy field to cocoa plantation.

\section{RESEARCH METHOD}

\subsection{Study Area}

This study was conducted in Terong Village, Bantul Regency. This location was purposively selected because Bantul Regency announced that this village become the center of cocoa plantation in this regency. This program was made because the government thought that this area has potency in developing cocoa plantation, and the government wants to lift the people's economy in this village. Moreover, another issue is land use change to cocoa plantation from the paddy field is occurred here. It is a dilemma for people and the government itself.

\subsection{Sampling procedure and data collection}

The data in this study were collected from 44 non-cocoa farmers and 16 cocoa farmers. Those respondents were chosen randomly, and interviewed using a designated questionnaire. This questionnaire consists of two main questions, first about their demographic such as age, education, farm size, and income, second about their response regarding land use change from the paddy field to cocoa plantation. The response is divided in to three variables, and they are knowledge (cognitive), attitude (affective) and action (conative).

\subsection{Analytical technique}

Descriptive method was used in this study as a basic method. The percentage was used to present the demographic conditions. Scoring technique and spearman rank were used to analyse the farmer' response toward agriculture land use change based on knowledge (cognitive), attitude (affective) and action (conative). Knowledge (cognitive) was measured with how farmers think relating to the response of farmers to the land use change of paddy fields to cocoa plantations. Attitude (affective) was measured with how farmers response to current problems. Meanwhile actions (conative) was measure with how the actions taken by farmers on the land use change of rice fields to cocoa plantations and discussion of farmers responses.

\section{RESULTS AND DISCUSSION}

\subsection{Demographic Features of Respondents}

As seen in Table 2, respondents in this study is majority is quite old, they are in range $47-56$ years old (52\%). Range $37-$ 46 years old is only $23 \%$. Aging farmers is happening everywhere, this issue is becoming concern for many parties, but no significant solution yet. [8] showed that aging farmers also happen in Thailand, and need to be solve to save future agriculture.

Less educated farmers is common trend in developing countries, including Indonesia. In their generations, education was not considered as important in life. The plurality of respondents are elementary school $(43.3 \%)$ and junior high school $(46.7 \%)$. Meanwhile no respondents who graduated from higher education.

The experience of farming respondents who have been interviewed varies. The following is the experience of farming based on the length of farming can be seen in Table 2. How long farmers have been doing their farming become the factor that effecting their decision making (Peltonen 2020). Majority of respondents have farming experience in range $18-25$ years $(50 \%)$. And common trend show that farmers start to be a farmer in 20 s, so it has connecting with the age of respondents where majority in age 47-56 (52\%).

Farm size is the area of land owned by respondents that is used for various types of agricultural cultivation. The following is the area of land based on land ownership can be seen in Table 2. It is common thins in developing countries that farmers' farm size is small. There is no respondents who have farm size more than 1 ha. The plurality of respondents are owning 5,000-6,999 $\mathrm{m} 2$ (35\%) and 3,000-4,999 (31.7\%). How large the farm size is effecting farmers' decision making [9].

Farmer's income is derived from basic work and side jobs, the income earned is the total acquisition from farming.

Table 2. Demographic of Respondents

\begin{tabular}{|c|c|c|c|}
\hline Category & $\begin{array}{r}\text { Per- } \\
\text { centage }\end{array}$ & Category & $\begin{array}{c}\text { Per- } \\
\text { centage }\end{array}$ \\
\hline Age (Year) & & $\begin{array}{l}\text { Farm size } \\
\left(\mathrm{m}^{2}\right)\end{array}$ & \\
\hline $37-46$ & 23 & $1,000-2,999$ & 23.3 \\
\hline $47-56$ & 52 & $3,000-4,999$ & 31.7 \\
\hline $57-66$ & 15 & $5,000-6,999$ & 35 \\
\hline $67-76$ & 10 & $7,000-9,000$ & 10 \\
\hline \multicolumn{2}{|c|}{$\begin{array}{l}\text { Farming Experience } \\
\text { (Year) }\end{array}$} & $\begin{array}{l}\text { Income } \\
\text { (IDR) }\end{array}$ & \\
\hline $10-17$ & 38.3 & $\begin{array}{l}500,000- \\
999,000\end{array}$ & 53 \\
\hline $18-25$ & 50 & $\begin{array}{l}1,000,000- \\
1,499,000\end{array}$ & 28 \\
\hline $26-33$ & 6.7 & $\begin{array}{l}1,500,000- \\
1,999,000\end{array}$ & 15 \\
\hline $34-41$ & 5 & $\begin{array}{l}2,000,000- \\
2,500,000\end{array}$ & 3 \\
\hline \multicolumn{2}{|l|}{ Education } & & \\
\hline $\begin{array}{l}\text { Elementary } \\
\text { School }\end{array}$ & 43.3 & & \\
\hline $\begin{array}{l}\text { Primary } \\
\text { School }\end{array}$ & 46.7 & & \\
\hline High School & 10 & & \\
\hline
\end{tabular}


Majority respondents only can earn from farming in range IDR 500,000 - IDR 999,000 per season (3 to 4 months). This income is difficult for fulfilling farmers' family need. Therefore, farmers often putting farming as second job or they are doing another job

\subsection{Response}

\subsubsection{Knowledge}

Response of knowledge (cognitive) to land use change from paddy fields to cocoa plantation is categorized in "sufficiently know" category. Total score of the category is 15.2 which means enough in knowledge regarding land use change from paddy field to cocoa plantation.

\subsubsection{Attitude}

The attitude (affective) response to the land use change from paddy fields to cocoa plantations is "quite like" category. The category has total score 14.5 which mean enough in attitude variable. This attitude including farmers attitude towards the cocoa centre program, cocoa cultivation, switching function of land, land conversion, the impact of switching function of land, the fact of land switching function of land and the development of switching function of land.

\subsubsection{Action (Conative)}

50 percent farmers answered "don't care" about the land use change. They think that the land use change still within agriculture practice, so it does not matter whether for paddy field or cocoa. Then 26.6 percent answered "care but do land use change" and only 23.4 percent "care and do not do land use change".

\subsection{Factors Effecting Response}

Table 3 Rank Spearman Results

\begin{tabular}{llll}
\hline \multirow{2}{*}{ Factor } & \multicolumn{3}{c}{ Correlation Coefficient (r) } \\
\cline { 2 - 4 } & $\begin{array}{l}\text { Knowledge } \\
\text { (Cognitive) }\end{array}$ & $\begin{array}{l}\text { Attitud } \\
\text { e } \\
\text { (Affecti } \\
\text { ve) }\end{array}$ & $\begin{array}{l}\text { Action } \\
\text { (Conati } \\
\text { ve) }\end{array}$ \\
\hline Age & 0.124 & 0.086 & 0.172 \\
Education & $0.319^{*}$ & 0.084 & 0.068 \\
Farming & & & \\
Experience & -0.043 & -0.050 & 0.181 \\
Farm size & -0.069 & 0.038 & $0.287^{*}$ \\
Income & -0.136 & $-0.291^{*}$ & 0.173 \\
\hline
\end{tabular}

* Significant Correlation at level 0.05

Between age with knowledge (cognitive), attitude (affective), and action (conative) there is no significant correlation. This means that the farmers' age whether young or old does not significantly affect or change the knowledge (cognitive), attitude (affective), and action (conative) of land use change.
Between education and knowledge (cognitive) has a significant positive relationship. The majority of farmers have a junior high school education with a percentage of 46.7 percent and also knowledge (cognitive) with score of 15.2 which is included in the category of enough to know, this condition make the education has significant positive effect on knowledge (cognitive). It means, there is a tendency where the higher the education of farmers, the higher the knowledge (cognitive) that farmers get from the land use change from paddy fields to cocoa plantations.

Between the experience of farming with knowledge (cognitive), attitude (affective), and action (conative) there is no significant correlation. This means that good or longstanding farming experience can't significantly influence or effect knowledge (cognitive), attitude (affective), and action (conative) of the land use change from paddy fields to cocoa plantations.

Based on table 3 , farm size owning with action (conative) has positive significant correlation. It means bigger the farm size, so better the action and vice versa. Meanwhile, the area of land with knowledge (cognitive) and attitude (affective) there is no significant relationship.

Income and attitude (affective) has a significant negative correlation, means when the income is getting higher, the attitude become more not caring and vice versa. Meanwhile, income with knowledge (cognitive) and action (conative) there is no significant relationship.

\section{CONCLUSION}

The knowledge regarding land use change in general definition has score 15.2, which mean is enough to know, attitudes regarding land use change has score 14.5 which mean they are quite happy and actions toward land use change especially the change from paddy field to cocoa plantation is dominated by don't care action with $50 \%$ answer. Rank Spearman results show that education has positive correlation with knowledge (cognitive), farm size has significant correlation with action (conative) and income has significant correlation with attitude. Generally, farmers' response toward land use change are not bad because the change is agriculture to agriculture usage.

\section{AUTHORS' CONTRIBUTIONS}

Rizki Yusnanda: made research concept, collected data, analysed data and wrote the paper. Sriyadi: made research concept and Zuhud Rozaki: made research concept and wrote the paper.

\section{ACKNOWLEDGMENTS}

The authors would like to express big gratitude to Universitas Muhammadiyah Yogyakarta for supporting this research. 


\section{REFERENCES}

[1] Z. Rozaki, "Decrease of agricultural land and industry growth in Special Region of Yogyakarta," IOP Conf. Ser. Earth Environ., 2020.

[2] O. Wijaya, "Strategi Pengembangan Komoditas Pangan Unggulan dalam Menunjang Ketahanan Pangan Wilayah (Studi Kasus di Kabupaten Batang, Propinsi Jawa Tengah)," Agrar. J. Agribus. Rural Dev. Res., vol. 3, no. 1, pp. 48-56, 2017.

[3] B. Utomo, A. A. Prawoto, S. Bonnet, A. Bangviwat, and S. H. Gheewala, "Environmental performance of cocoa production from monoculture and agroforestry systems in Indonesia," J. Clean. Prod., vol. 134, no. Part B, pp. 583-591, 2016.

[4] A. Tothmihaly, V. Ingram, and S. von CramonTaubadel, "How Can the Environmental Efficiency of Indonesian Cocoa Farms Be Increased?," Ecol. Econ., vol. 158, no. March 2018, pp. 134-145, 2019.
[5] D. Harrison, "Cocoa, conservation and tourism Grande Riviere, Trinidad," Ann. Tour. Res., vol. 34, no. 4, pp. 919-942, 2007.

[6] BPS - Statistics Indonesia, "Daerah Istimewa Yogyakarta Dalam Angka 2018 (Special Region of Yogyakarta in Number 2018)," 2018.

[7] Z. Rozaki, "Carrying Capacity of Agriculture Sector Based on Commodities' Production in Kulonprogo Regency," 2020.

[8] P. Saiyut, I. Bunyasiri, P. Sirisupluxana, and I. Mahathanaseth, "Changing age structure and input substitutability in the Thai agricultural sector," Kasetsart J. Soc. Sci., vol. 38, no. 3, pp. 259-263, 2017.

[9] H. Lu, P. Zhang, H. Hu, H. Xie, Z. Yu, and S. Chen, "Effect of the grain-growing purpose and farm size on the ability of stable land property rights to encourage farmers to apply organic fertilizers," J. Environ. Manage., vol. 251, no. May, p. 109621, 2019. 